\title{
Dorota Konopka
}

\section{Polityka państwa w realiach kultury bezrobotnych jako subkultury ubóstwa. Na bazie koncepcji teorii pól Pierre'a Bourdieu}

\begin{abstract}
Streszczenie
$\mathrm{W}$ artykule powiązano perspektywę teoretyczną badań nad kulturą bezrobotnych $\mathrm{z}$ dorobkiem francuskiego socjologa Pierre'a Bourdieu, w tym z teorią pól. Pole (le champ) jest jedną z kluczowych kategorii jego teorii. Refleksyjna analiza pojęć teoretycznych P. Bourdieu jest pomocna, aby wyjaśnić przyczyny marginalizacji i wykluczenia na przykładzie długoterminowego bezrobocia. Analiza teoretyczna ukazała, że przyczyny marginalizacji tkwią nie tylko w samych jednostkach jej ulegających, ale także uwarunkowane są przemianami ogólnospołecznymi, strukturą społeczną danego państwa. Analizy Bourdieu są dobrą podstawą do programowania polityki publicznej, której celem jest ograniczanie społecznych i ekonomicznych skutków trwałego bezrobocia.
\end{abstract}

Słowa kluczowe: socjologia, polityka rynku pracy, kultura bezrobotnych, marginalizacja, wykluczenie społeczne, bezrobocie

\section{State Policy in the Reality of the Culture of the Unemployed as the Structure of Poverty: Based on Pierre Bourdieu's Theory of Fields}

\begin{abstract}
The article links the prospect of theoretical research on the culture of the unemployed with the achievements of French sociologist Pierre Bourdieu, including the theory of fields (le champ), which is one of the key categories of his theory. A reflexive analysis of P. Bourdieu's theoretical concepts is helpful to explain the reasons for marginalization and exclusion on the example of long-term unemployment. Theoretical analysis showed that the reasons for marginalization lie not only in the entities subject to marginalization, but also are conditioned by general social changes, the social structure of a given country.
\end{abstract}


Bourdieu's analyses are a good basis for programming public policy, the aim of which is to limit the social and economic effects of permanent unemployment.

Keywords: sociology, labour market policy, culture of the unemployed, marginalization, social exclusion, unemployment

Transformacja ustrojowa zapoczątkowana w Polsce pod koniec lat 80. XXw. przyniosła wiele zmian, zarówno pozytywnych, jak i negatywnych, w niemal wszystkich obszarach państwa: społecznym, gospodarczym, a także w sferze politycznej. Wysokie bezrobocie pojawiło się jako jej negatywny rezultat i stało się problemem społecznym numer jeden na wiele lat. $Z$ czasem okazało się jednym $\mathrm{z}$ ważniejszych, a być może nawet decydującym kryterium podziału społecznego - na beneficjentów i przegranych transformacji, „lepszych i gorszych”. M. Jarosz i M.W. Kozak (2015) w swojej monografii Eksplozja nierówności? określili, że zachowania jednych i drugich wykazują mechanizmy samonapędzające się. Ci, którym się powiodło, dalej pomnażają swoje profity. Przegrani, nie widząc poprawy swojej sytuacji, w ogóle przestają walczyć, a swoją biernością przyspieszają własną marginalizację (Jarosz i Kozak, 2015: 88-89; Merton, 1968). Długotrwałe bezrobocie prowadzi do rezygnacji, nie do rewolucji (Naylor i Senior, 1988), a w pewnych regionach o wysokiej stopie bezrobocia może doprowadzić do powstania sfer ubóstwa, a nawet dziedziczenia biedy i bezrobocia (Szylko-Skoczny, 1987: 31). E. Mączyńska celnie stwierdziła, że polska transformacja pozostawiła po sobie „ostrzegawczy dekalog zagrożeń, nierównowag i nieprawidłowości” (Mączyńska, 2009: 1).

Od 2015 r. poziom bezrobocia w Polsce dynamicznie spada i stał się rekordowo niski. Według danych GUS liczba bezrobotnych zarejestrowanych w urzędach pracy w latach 2011-2018 pokazuje wyraźną tendencję spadkową. W końcu stycznia $2018 \mathrm{r}$. stopa bezrobocia rejestrowanego wyrównana sezonowo wyniosła 6,5 proc. i zmalała w stosunku do 2011 r. o 5,8 proc. Na przestrzeni siedmiu lat liczba bezrobotnych zmniejszyła się o 904,3 tys. (GUS, 2018). Podobny wskaźnik bezrobocia odnotowano w 1991 r., czyli 27 lat temu. Jak wynika z danych urzędów pracy, obecny spadek liczby bezrobotnych był wynikiem spadku napływu do bezrobocia przy jednoczesnym wzroście odpływu. Powyższy sukces w polityce rynku pracy nie jest wynikiem rozmyślnych działań czy implementacji szczególnie innowacyjnych koncepcji, a raczej skutkiem niżu demograficznego, emigracji zarobkowej, a także dobrej koniunktury na rynkach eksportowych.

W Polsce poważnym problemem pozostaje jednak kwestia bezrobocia długoterminowego. Niestety, bezrobocie ma u nas w przeważającym stopniu charakter 
bezrobocia długotrwałego. Według raportu z badań CBOS „Bezrobotni 2017” 66 proc. bezrobotnych pozostaje bez pracy dłużej niż rok, w tym 21 proc. nie ma zatrudnienia od ponad 2 do 5 lat; a jedna trzecia - od 5 lat (CBOS, 2017).

Minister E. Rafalska stwierdziła, że niskie bezrobocie zmusza firmy do sięgnięcia po nowe grupy, które dotychczas nie pracowały, a więc m.in. ludzi młodych studiujących. Jest to wciąż niestety niepopularne w Polsce, bo mogą oni pracować w niepełnym wymiarze godzin. Inną grupą, stwierdza minister Rafalska, „są osoby długotrwale bezrobotne, które są jednak trudne do aktywizacji, bo przez wiele lat były oddalone od rynku pracy" (Business Insider Polska, 2017).

Warto zauważyć, że od lat 60 . XXw. w światowej socjologii, antropologii czy polityce społecznej przetaczały się wielkie debaty na temat koncepcji biedy, kultury ubóstwa, underclass, dependency culture, marginalizacji, social exclusion i wielu innych. W Polsce niestety aż do początku lat 90 . takie dyskusje nie miały prawa bytu lub toczyły się w bardzo ograniczonym zakresie. Natomiast liczne dotychczasowe badania prowadzone przez wielu wybitnych socjologów od lat wskazują na występowanie w zaostrzonej postaci problemu nierówności społecznych, biedy, wykluczenia i marginalizacji (Toczyński, 1991; Kraczla, 1993; Warzywoda-Kruszyńska i Grotowska-Leder, 1996; Warzywoda-Kruszyńska i Jankowski, 2013; Zalewska, 1997), kultury ubóstwa (Kraczla, 1993; Kowalak, 1998; Osińska i Śliwińska, 1997), underclass i społecznej marginalizacji (Wódz, 1994; Frieske i Sikorska, 1994; Warzywoda-Kruszyńska i Grotowska-Leder, 1996; 2013; Popławski, 1997; Kowalak, 1998; Bauman, 1998; Frieske, 1999; 2008). Polityka publiczna w powyższym zakresie nie odnotowywała widocznych sukcesów czy wręcz stała się obszarem porażek.

Zauważalnym problemem analizy współczesnych społeczeństw jest to, że brakuje odpowiednich instrumentów teoretycznych, które pozwalałyby na trafny opis i zrozumienie zachodzących zmian społecznych, a także na podejmowanie niezbędnych i ważnych działań praktycznych w postaci polityki/interwencji publicznych - zarówno na szczeblu globalnym, jak też i odpowiednio lokalnym. Wybitny francuski socjolog, przedstawiciel socjologii refleksyjnej i humanistycznej, P. Bourdieu celnie stwierdził, że „...badanie bez teorii jest ślepe, a teoria bez badań pusta” (Bourdieu i Wacquant, 2001: 155).

Celem artykułu jest przedstawienie (analityczna konfrontacja) teoretycznego dorobku P. Bourdieu w odniesieniu do problematyki marginalizacji i wykluczenia we współczesnym świecie w kontekście bezrobocia i biedy. Bourdieu zwracał uwagę na marginalizowanie socjologii i niedocenianie wiedzy socjologicznej przez władze polityczne, które „(...) oczekują od nauk społecznych nie znajomości prawdy o świecie społecznym, ale instrumentów racjonalnej demagogii (...), tyranii ankiet marketingowych". Bourdieu, włączając do nauk społecznych prakseologię, umiejętnie 
kierował swoje analizy w kierunku teorii działania, pozostawiając swój dorobek jako praktyczną teorię (Bourdieu, 2013: 3-12). Perspektywę teoretyczną badań nad kulturą bezrobotnych powiązano w artykule $\mathrm{z}$ teorią pól. Pole (le champ) jest jedną z kluczowych kategorii teorii Pierre'a Bourdieu (Bourdieui Wacquant, 2001: 76-99).

Pomysł na wykorzystanie teorii P. Bourdieu w badaniach nad kulturą bezrobotnych pojawił się po realizacji moich autorskich badań empirycznych pt. „Społeczno-kulturowe uwarunkowania bezrobocia regionu białostockiego". Celem teoretycznym badań było ustalenie, jakie powiązania występują między wybranymi elementami struktury społecznej i kultury a bezrobociem, w szczególności interesowało mnie, czy mamy do czynienia z kształtowaniem się kultury bezrobotnych jako kompleksu trwałych postaw i wzorów zachowań związanych z bezrobociem na przykładzie bezrobotnych regionu białostockiego. Cel praktyczny badań dotyczył ustalenia stopnia zagrożenia płynącego z formowania się kultury bezrobotnych w Polsce, jak i czynników, które temu przeciwdziałają (Konopka, 2009).

\section{Bezrobocie jako symboliczne pole (le champ) struktury społecznej}

Refleksyjna analiza pojęć teoretycznych P. Bourdieu jest pomocna w wyjaśnieniu przyczyn marginalizacji. Otóż tkwią one nie tylko w samych jednostkach ulegających marginalizacji, ale także uwarunkowane są przemianami ogólnospołecznymi, strukturą społeczną i polityką publiczną danego państwa.

Wielu autorów nie przywiązuje dużej wagi do analizy uwarunkowań strukturalnych (obiektywnych), które sprawiają, że dochodzi do odsunięcia jednostek i całych grup na margines życia społecznego (Dyczewski, 2007: 39-40). Często polityka państwa jest wobec tego bezradna. Autorzy polityki projektujący interwencje publiczne nie uwzględniają całej złożoności realiów społeczno-ekonomicznych i ich oddziaływania na słabsze grupy społeczne. Rozwiązując jedne problemy, zaostrzają inne, w tym te, które dotykają słabszych.

Bezrobocie jest przedmiotem zainteresowania wielu dziedzin nauki, tj.: prawa, ekonomii, socjologii, psychologii, demografii czy statystyki. Każda z tych nauk wykorzystuje definicje pozwalające realizować odmienne cele poznawcze. Przedstawiając definicję ekonomiczną bezrobocia (najczęstsze ujęcie w debacie publicznej), ekonomista posługuje się tzw. „przedmiotowym” rozumieniem bezrobocia. Definicja ta ujmuje bezrobocie jako parametr rynku pracy, skupia uwagę na zmiennych w czasie, wyrażonych liczbowo, wzajemnych proporcjach popytu i podaży „siły roboczej”. W ekonomii bezrobocie nie jest uznawane za najbardziej niepożądane zjawisko (gdy 
pozostaje w pewnych ramach). W $1967 \mathrm{r}$. M. Friedman oznajmił, że istnieje poziom bezrobocia (koncepcja naturalnej stopy bezrobocia - NAIRU - Non-Accelerating Inflation Rate of Unenployment), który jest dobry dla gospodarki. Rządy oraz banki centralne nie powinny próbować schodzić poniżej tego poziomu nawet za cenę społecznego niezadowolenia. Od kilkudziesięciu lat jest to fundamentem nie tylko amerykańskiej, ale i światowej polityki ekonomicznej. W odróżnieniu od powyższego podejścia można wyróżnić podejście „podmiotowe”, w którym rozpatruje się bezrobocie z punktu widzenia osób dotkniętych brakiem pracy (socjologiczno-psychologiczne analizy) (Borkowski i Marcinkowski, 1999: 17).

Bezrobocie, szczególnie bezrobocie strukturalne i dziedziczone, staje się przyczyną marginalizacji społecznej, swoistego naznaczenia w nowoczesnym społeczeństwie. W wyniku tego procesu mogą się wytworzyć przesłanki do tworzenia kultury bezrobotnych (czyli, parafrazując P. Bourdieu, reguły zachowań (ilussio) warunkowanych przez habitus, które przyjmują jednostki w grze) $)^{1}$.

Osoby trwale bezrobotne przyjmują różne strategie zachowań w sytuacji pozostawania bez pracy (np. konformistyczną, rytualistyczną, zrezygnowaną, przedsiębiorczą, kalkulującą, autonomiczną) (Engbersen et al., 1993: 15-179). Podlegają one procesowi przystosowania się do subkultury ubóstwa m.in. przez to, że ograniczają do minimum realizację potrzeb i dążeń. Kulturę bezrobotnych należałoby więc traktować jako typ subkultury ubóstwa wytworzonej w sytuacji bezrobocia. Powyższe realia sprawiają, że polityka rynku pracy czy aktywizacji bezrobotnych staje się niesłychanie trudna w realizacji.

Zatem kulturę bezrobotnych określam jako ogół trwałych wytworów życia zbiorowego bezrobotnych stanowiących wewnętrznie powiązaną całość, obejmujących szczególnie zachowania przebiegające według wspólnych dla zbiorowości bezrobotnych wzorów, ukształtowanych i przyswajanych w toku interakcji. Definicja ta została sformułowana na podstawie definicji kultury A. Kłoskowskiej (Kłoskowska, 1993: 77-200).

Teoria pól P. Bourdieu odnosi się do mikrostruktury i stanowi dynamiczny, zmienny układ stosunków między jednostkami, których miejsce określa się w relacji do konkurentów produkujących dobra symboliczne na tym samym polu. Inaczej, pole oznacza wycinek struktury społecznej, który charakteryzuje się tym, że skupia jednostki i grupy skoncentrowane na podobnych dążeniach i rywalizujące o pozycję

1 Czynniki i tendencje sprzyjające formowaniu się kultury bezrobotnych, jak i czynniki ograniczające mechanizm tworzenia kultury bezrobotnych zostały opracowane na podstawie badań empirycznych autorki „Społeczno-kulturowe uwarunkowania bezrobocia regionu białostockiego”, zrealizowanych na próbie 384 bezrobotnych metodą wywiadu kwestionariuszowego. Obszerne wyniki badań zostały zamieszczone w monografii (Konopka, 2009). 
w jego obrębie, a pośrednio w całym społeczeństwie, wedle obowiązujących w tym polu kryteriów, wokół obowiązujących w nim centralnych założeń i celów uznawanych za szczególnie ważne. Cele te nazywa czasem Bourdieu stawką w grze, jaka się toczy w polu, a założenie o priorytetowym charakterze tej stawki mianem obowiązującego w tym polu illusio. Pole to mikrokosmos wewnątrz wszechświata społecznego, rządzący się swoją logiką, posiadający względną autonomię, przez co wytwarza właściwy sobie rodzaj praktyk i układów stosunków między uczestnikami. Przykładami pól według Bourdieu są: gospodarka, polityka, sztuka, nauka, religia, oświata. Bourdieu nie analizował w swoich pracach problemu bezrobocia jako swoistego układu stosunków i relacji między bezrobotnymi. Jednak refleksyjne propozycje zrozumienia mechanizmów przedstawione w postaci uniwersalnych i kontekstowych pojęć dają możliwości przełożenia na inne zjawiska. Moim zdaniem przykładem takiego pola jest również system organizacyjny bezrobocia, a ściśle bezrobocie.

Pole można łączyć z symbolicznym obszarem zajmowanym przez bezrobotnych, obszarem coraz bardziej wspólnym ogółowi bezrobotnych, a jednocześnie wyodrębnionym względem innych. Zdaniem Bourdieu pole to miejsce, na którym toczy się gra. Pole jest systemem lub układem zorganizowanym bezrobotnych, takim, jaki możliwy jest do wyodrębnienia w praktyce.

W obrębie wyróżnionego pola kształtują się wspólne założenia, cele, czyli stawki w grze, o które toczy się walka. Tymi celami są przede wszystkim ponowne uzyskanie pozycji w strukturze zawodowej, ponowne podjęcie pracy zawodowej, ale także stawką w grze może być walka o przetrwanie, dostosowanie się w warunkach bezrobocia.

Bezrobotni dopiero po pewnym czasie poznają, jakie są ich interesy strategiczne, jakie są wartości stawek zaangażowanych i według jakich reguł mogą być osiągane.

\section{Habitus jako system schematów percepcji, oceniania i działania bezrobotnego}

Utrata poczucia bezpieczeństwa w kręgu pracujących i dążenie do przebywania wśród równych sobie - niepracujących, to jeden z głównych czynników sprzyjających formowaniu się symbolicznego pola bezrobotnych i kultury bezrobotnych. Jednostka, tracąc rolę zatrudnionego, usuwana jest $\mathrm{z}$ kręgu ludzi pracujących. Zamiast tego tworzy się wokół niej nowy krąg społeczny, składający się z ludzi, którymi interesuje się lub którzy wykazują zainteresowanie daną jednostką z powodu jej bezrobocia. Im bardziej zacieśnia się krąg bezrobotnego, tym trudniej jest w jego ramach żyć i tym trudniej się z niego wydostać. Pozostawanie w sytuacji bezrobotnego narusza podstawową potrzebę człowieka, jaką jest bezpieczeństwo. W dłuższym okresie jej 
zaspokojenie dokonuje się w wyniku narastania kontaktów z innymi bezrobotnymi. Następuje dążenie do przebywania wśród równych sobie - niepracujących.

Liczba bezrobotnych skupionych wokół jednostek pozbawionych pracy wzrasta wraz z czasem trwania okresu bezrobocia. Na pewno zjawisko bezrobocia przyczynia się do stworzenia lub poszerzenia nowego kręgu społecznego, często kosztem innych kręgów społecznych.

Bezrobotni w relacjach z osobami pracującymi mogą czuć się gorsi. Samookreślenie, że jest się gorszym ze względu na brak pracy, może świadczyć już o tworzącej się izolacji, poczuciu wyobcowania i w konsekwencji odsunięcia od społeczeństwa (marginalizacji). Mamy więc do czynienia z kolizją wartości i norm postępowania kategorii pracujących i niepracujących. Teoretyczne odniesienie do tego typu zjawisk znaleźć można w koncepcji konfliktu kultur T. Sellina. Duży stopień zróżnicowania kulturowego rodzi, zdaniem Sellina, nieuchronny konflikt wartości i norm postępowania, który wywołuje zachowania dewiacyjne (Siemaszko, 1993: 84). Ponadto wartość wspólnotowa, podkreślająca znaczenie interakcji w obrębie społeczności lokalnych, może zostać przesunięta na plan dalszy wśród naczelnych wartości. Świadczyć to może o następującej zmianie i skupianiu uwagi nie na życiu wśród społeczności lokalnych, ale na życiu zindywidualizowanym. Sytuacja bezrobocia warunkuje narastanie kontaktów nieformalnych, które z czasem górują nad kontaktami formalnymi. Narastająca izolacja względem instytucji publicznych ogranicza możliwości znalezienia nowej pracy.

$\mathrm{Na}$ polu wyznaczonym przez zachowania bezrobotnych toczy się gra, walka, rywalizacja o osiąganie celów według reguł uznanych, ale także według reguł żywiołowych naruszających ukształtowane wzory zachowań.

Jak zachowują się bezrobotni w swoim polu, w podstawowej mierze decyduje ich habitus (Bourdieu i Wacquant, 2001: 100-130), a o tym, jakie mają szanse na wygranie stawek w grze, decyduje ich kapitał. Habitus określa to, jak umiemy grać, a kapitał określa środki, jakimi dysponujemy w grze. Stworzona przez P. Bourdieu koncepcja habitus określa system schematów myśli, percepcji, oceniania i działania. Jest to zdeponowane we wnętrzu jednostek całe doświadczenie życiowe, które uzewnętrznia się w postaci przyswojonych wzorów zachowań. Habitus to droga życiowa jednostek i przyswojone doświadczenie. Koncepcja ta zakłada, że habitus jest to całe przyszłe i obecne otoczenie określonej osoby. Obejmuje to także osobiste wierzenia, skłonności oraz sposoby rozwiązywania problemów (wybór drogi, odpowiednie zachowanie). Teoria habitus pośrednio kwestionuje założenia koncepcji wolnej woli, z racji tego, że zakłada ograniczoną (przez usposobienie czy gotowość do działania) możliwość wyboru. Całkowite poznanie habitus, nie osoby, nie jest jednak możliwe ze względu na fakt, że jest on prawdopodobnie zakorzeniony w podświadomości (Bourdieu, 
2006: 546-558). Zdaniem Bourdieu, jednostka zostaje w taki sposób ukształtowana, że w swoim postępowaniu kieruje się nadal narzuconymi regułami, a to prowadzi do reprodukcji. W sytuacji bezrobocia możemy mówić o problemie nawet dziedziczenia (reprodukcji) bezrobocia i z tym związanego habitus, które jest cechą charakterystyczną kultury bezrobotnych.

Według Bourdieu każda jednostka posiada habitus pierwotny i habitus wtórny (powstający na bazie habitus pierwotnego). Kulturę bezrobotnych, która stanowi wewnętrznie powiązaną całość, obejmującą szczególnie zachowania przebiegające według wspólnych dla zbiorowości bezrobotnych wzorów, ukształtowanych i przyswajanych w toku interakcji i coraz częściej przekazywanych innym, określa także nabyty habitus bezrobotnego. Habitus ten jest zachowaniem w miarę regularnym, uświadamianym i wprowadzonym w sferę ludzkich nawyków. Cechy habitus bezrobotnego zależą na pewno od kontekstu kulturowego, który w polskim społeczeństwie możemy porównać ze stereotypem bezrobotnego. Są to takie cechy jak: leniwy, niewykształcony, niezaradny, pesymista.

W swoim polu bezrobotni dysponują również określonym kapitałem społecznym i kulturowym. Kapitałem może być wszystko, czym jednostka dysponuje lub to, co może uruchomić (znajomości, układy, pamięć doświadczeń zawodowych, wykształcenie itp.), aby osiągnąć zamierzone cele. Kapitałem jest to, co pozwala bezrobotnym przynajmniej zaistnieć w polu, osiągać cele, być porównywalnym $z$ innymi lub lepszym od innych.

Należy zwrócić uwagę, że w polu bezrobocia występuje kilka ważnych instytucji, organizacji, grup nieformalnych, które wpływają na zachowania bezrobotnych. Są to urzędy pracy, instytucje pracy, rodziny, struktury koleżeńskie i inne. Zależnie od habitus, którym dysponuje bezrobotny, mają one większy lub mniejszy wpływ na wybory zachowań bezrobotnych.

Podsumowując, w badaniach nad kulturą bezrobotnych w perspektywie koncepcji teoretycznej P. Bourdieu należałoby przede wszystkim zweryfikować pole (system) i te reguły zachowań (ilussio) warunkowanych przez habitus, które przyjmują jednostki w grze oraz kapitał, jakim dysponują, pozwalający jednostkom osiągnąć cele w systemie. Ponadto, ważną kwestią jest, aby odnieść pole bezrobotnych jako system lub układ zorganizowany do miejsca w hierarchii struktury społecznej. Jeżeli zajmuje ono bardzo niskie miejsce w społecznej strukturze, to jest w zasadzie obiektem manipulacji i marginalizacji. 


\section{Wykluczenie społeczne jako nowoczesna przemoc symboliczna współczesnego świata}

Bezrobocie długotrwałe i dziedziczone staje się przyczyną marginalizacji społecznej. Jak już wspomniano, w wyniku tego procesu mogą powstać przesłanki do tworzenia kultury bezrobotnych. Przyczyny marginalizacji nie tylko tkwią w samych jednostkach ulegających marginalizacji, ale także uwarunkowane są strukturalnie, czyli wynikają ze sposobu funkcjonowania społeczeństwa, w tym organizacji polityki publicznej, która często defaworyzuje słabsze ekonomicznie grupy. Dokonuje się to niedobrowolnie, w formie wywieranej na nie przemocy. Proces narzucania określonej wizji rzeczywistości społecznej oraz wiążącej się z nią hierarchii wartości P. Bourdieu nazwał przemocą symboliczną (przykładami przemocy symbolicznej wg Bourdieu są m.in. relacje między płciami, wyzysk w okresach feudalizmu) (Bourdieu, 2006: 503-508). Zdaniem Bourdieu, proces ten zachodzi w kontaktach międzykulturowych oraz w obrębie danego społeczeństwa - w trakcie kształcenia i socjalizacji. Polega na uzyskiwaniu różnymi drogami takiego oddziaływania klas dominujących czy uprzywilejowanych na całość społeczeństwa i na klasy podporządkowane, by podporządkowani postrzegali rzeczywistość, w tym samą relację dominacji, której są ofiarą, w kategoriach percepcji i oceny, które wyrażają interes klas dominujących. W ten sposób podporządkowani postrzegają swoją sytuację jako naturalną lub nawet korzystną czy pożądaną dla nich samych, bo postrzegają rzeczywistość społeczną w kategoriach stworzonych i narzuconych przez klasy dominujące w celu legitymizacji ich dominującej pozycji. Obok różnych strategii zachowań w sytuacji pozostawania bez pracy (konformistycznej, rytualistycznej, zrezygnowanej, przedsiębiorczej, kalkulującej itp.) następuje proces przystosowania się do subkultury ubóstwa przez ograniczenie do minimum realizacji potrzeb i dążeń. Akceptacja tego obrazu w istotny sposób wpływa na procesy ruchliwości społecznej (zwłaszcza ruchliwości pionowej, tzn. możliwości awansu i kariery życiowej, wyjścia z pułapki bezrobocia) w obrębie pola, jak i na zewnątrz niego. Funkcjonujące mechanizmy selekcji prowadzą do reprodukcji, czyli odtwarzania istniejących zróżnicowań (dziedziczenia).

Przemoc symboliczna, zdaniem Bourdieu, jest najskuteczniejszą formą sprawowania władzy nad klasami podporządkowanymi, gdyż z reguły nie dostrzegają one nawet, że jest to forma przemocy. Są one przekonane, że to naturalny porządek, że osoby i grupy społeczne posiadające duży kapitał symboliczny po prostu są lepsze i ich lepsze społeczne usytuowanie jest normalne, nie poddają go więc refleksji.

$\mathrm{W}$ wypadku bezrobotnych przejawem utrzymującej się przemocy symbolicznej jest przede wszystkim ich przekonanie, że są gorsi, że dysponują gorszymi, niższymi 
kompetencjami zawodowymi, a także społeczno-kulturowymi w porównaniu $\mathrm{z}$ kategorią pracujących. W tym kontekście pojawia się niezwykle ważny społeczny skutek bezrobocia, czyli kluczowy podział na „my” i „oni”. Na co dzień obserwujemy wszechobecność tych podziałów. Potrzeba istnienia in-group w opozycji do out-group jest powszechna i ponadkulturowa. Ogólnie można stwierdzić, że ludzie dzielą świat społeczny na „swoich” i „obcych”, przy czym stosunek do „swoich” ma charakter protekcjonistyczny (Czykwin, 2000: 15). Grupa „obcych” (bezrobotnych) żyje w społeczeństwie, ale jednocześnie nie jest elementem aktywnego rozwoju społeczeństwa. Bardzo często traktowani są jako obcy i sami to odczuwają. Następuje kształtowanie swoistego negatywnego stereotypu, można określić, że następuje kategoryzacja czy nawet stygmatyzacja jednostek i grup społecznych, spychanie ich poza główne nurty życia społecznego (Dyczewski, 2007: 31-32). „Kategoryzacja”, jak twierdzi E. Czykwin, „wiąże się z przecenianiem podobieństwa wzajemnego osób - reprezentantów grupy obcej, co wiąże się z przecenianiem podobieństwa wzajemnego osób - reprezentantów grupy, co związane jest $z$ pozbawieniem ich cech indywidualnych oraz postrzeganiem grupy własnej jako wysoce indywidualnie zróżnicowanej. Taki stan stwarza tendencje do zwiększania dystansu pomiędzy grupami” (Czykwin, 2000: 20).

J.C. Turner zbudował tzw. hipotezę stereotypizacji Ja (Bikont, 1988), w której akcentowane jest podobieństwo między członkami grupy własnej. Jej uczestnicy reagują na siebie i inne osoby z grupy nie jak na osoby posiadające indywidualne biografie i swoiste problemy, ale jak na egzemplarze grupy o wspólnej charakterystyce. W warunkach, w których tożsamość społeczna wyłącza tożsamość osobistą, podmiot ulega depersonalizacji.

Zdaniem Turnera, takie czynniki jak: konflikt, konfrontacja lub spotkanie z inną grupą, odrębność własnej grupy od otoczenia; posługiwanie się cechami kryterialnymi, bliskość, podobieństwo, wspólnota celów; sytuacja, kiedy osoby spoza grupy zachowują się nie jako suwerenne jednostki, ale jako członkowie grupy - sprzyjają depersonalizacji. Ponadto Turner zakłada, że akcentowanie tożsamości społecznej kosztem tożsamości osobistej prowadzi do zwiększenia otwartości na innych z własnej grupy i do zamknięcia się w jej ramach.

Natomiast stygmatyzujący proces, w którym nadaje się etykietę osobom niespełniającym oczekiwań innych, wpływa zwrotnie na sposób myślenia jednostki stygmatyzowanej o sobie w kategoriach zawartych w stygmacie. Jednostka zaczyna wierzyć $\mathrm{w}$ dysponowanie przypisywanymi właściwościami, utożsamia się z nimi i zachowuje zgodnie z treścią stygmatu, spełniając oczekiwania społeczne. Stygmatyzowana grupa bezrobotnych czuje bezsilność i bezradność z powodu braku wsparcia dla jej działań antystygmatyzujących. Powoduje to zmianę pozycji społecznej jednostek grup stygmatyzowanych, następuje odrzucenie przez otoczenie społeczne, które doprowadza do 
obniżenia poczucia własnej wartości. Dodatkowo widoczny staje się wzrost poczucia zagrożenia prowadzący do zachowań i stwierdzeń osób bezrobotnych, że „wszystko co robię, jest złe". Takie myślenie o sobie i swoim zachowaniu w kategoriach braku wpływu staje się regułą i dochodzi do izolacji społecznej, obniżenia nastroju. Pojawia się motywacja do zmiany sytuacji.

\section{$* * *$}

Marginalizacja osób bezrobotnych jest skutkiem przede wszystkim długotrwałego braku stabilnej pracy i dochodu. Prowadzi do trwałego wykluczenia społecznego (social exlusion) oraz powstawania kultury bezrobotnych, która również oddziałuje wykluczająco $z$ uwagi na wytwarzane wzorce, m.in. bierności, pogodzenia z sytuacją. $\mathrm{W}$ powyższych realiach polityka publiczna rozumiana jako interwencje $\mathrm{w}$ zastany stan rzeczy jest $\mathrm{z}$ natury trudnym przedsięwzięciem. Wymaga bowiem znacznych zasobów finansowych, ale także uwzględnienia złożoności problematyki wykluczenia, w tym świadomości, jak wiele sektorowych interwencji musi być dopasowanych do wyzwań polityki walki z wykluczeniem społecznym. Taka polityka wydaje się szczególnie trudna w państwie, które nie wyróżnia się sprawnością organizacyjną $\mathrm{w}$ realizacji zaprogramowanych interwencji, a także w sytuacji ogólnospołecznego poczucia bezradności wobec ogromu problemu.

Powyżej analizowane pojęcie wykluczenia społecznego nawiązuje do zjawiska anomii E. Durkheima - istnienia barier ładu społecznego uniemożliwiających ludziom normalne funkcjonowanie (Durkheim, 2006). Zbiorowości marginalne i wykluczone mają ograniczony dostęp do wielu dóbr publicznych (wartości publicznych). W tym kontekście w Polsce i na świecie pojawia się problem wielu społecznych nierówności (rozumianych jako społecznie nieakceptowane różnice): edukacyjnych, politycznych, zdrowotnych, kulturalnych, regionalnych itd. H. Domański zwraca szczególną uwagę na fakt, że w polskiej rzeczywistości wciąż „mechanizmy dziedziczenia nierówności edukacyjnych są trwałym ogniwem struktury społecznej” (Domański, 2009: 9). Najczęściej polityka/interwencje państwa nie są w stanie im sprostać czy nawet łagodzić nierówności. Dlatego dochodzi do ich reprodukcji, jak była mowa powyżej.

Warto zauważyć jednak, że po 2008 r., kiedy rozpoczął się globalny kryzys ekonomiczny, doszło do pewnej zmiany w dominującej perspektywie patrzenia na bezrobocie. Najnowsze rozważania czołowych światowych ekonomistów potwierdziły, że długotrwałe bezrobocie ma dla obywateli dużo gorsze skutki niż te dostrzegane przez neoklasyczne modele ekonomiczne. O. Blanchard, główny ekonomista Międzynarodowego Funduszu Walutowego w latach 2008-2015, podważając przykazania neoliberalnego konsensusu waszyngtońskiego (kanon polityki gospodarczej MFW oraz Banku Światowego), dowodzi w raportach MFW, że nierówności społeczne 
wręcz szkodzą gospodarce, ponadto podważa słuszność funkcjonowania koncepcji naturalnej stopy bezrobocia (Woś, 2017: 34).

Naturalną stopę bezrobocia, która może być powiązana $\mathrm{z}$ długotrwałym bezrobociem, socjologowie łączą z groźnym syndromem, jakim jest idea zbędności. Zygmunt Bauman trafnie ujął, że zbędność zakłada trwałość i naturalność danego stanu. „Być zbędnym znaczy być nadliczbowym, niepotrzebnym, bezużytecznym. (...) »zbędność« dzieli swe pole znaczeniowe z takimi słowami jak »odrzuty«, »wyrzutki«, »śmieci« - krótko mówiąc, odpady. Przeznaczeniem bezrobotnych, tej »rezerwowej armii pracy«, był powrót do czynnej służby. Przeznaczeniem odpadów jest śmietnik" (Bauman, 2004: 25). Problem zbędności w sytuacji bezrobocia ma dwie strony: po pierwsze, poczucie bycia zbędnym przez samego bezrobotnego (poczucie bezsensu, marazm i apatia prowadzące do wycofania się z życia społecznego, ekonomicznego), po drugie, uznanie przez społeczeństwo bezrobotnych za ludzi zbędnych, co jest bardzo niebezpiecznym zjawiskiem.

W tej sytuacji wydaje się bardzo potrzebne znalezienie wspólnego mianownika metodologicznego między ekonomią, polityką gospodarczą i socjologią oraz trafny dobór wspólnych kategorii badawczych. Nie uda się tego osiągnąć bez zastosowania podejścia interdyscyplinarnego i interproblemowego. T. Kowalik napisał: „Trudność rzeczywistego dialogu wynika także stąd, że oparta na paradygmacie neoklasycznym ekonomia dorobiła się wysoce wysublimowanego, skomplikowanego aparatu badawczego, na podstawie którego socjologowie kompletnie dyskutować nie potrafią" (Kowalik, 2013: 413).

Konkludując, perspektywa teoretyczna francuskiego socjologa w badaniach nad kulturą bezrobotnych jako subkulturą ubóstwa jest interesującą drogą analizy tych czynników, które przyczyniają się do utrwalenia zjawiska długoterminowego bezrobocia. Analizy Bourdieu pozwalają na głębsze zrozumienie mechanizmów powstawania i utrwalania się trwałego bezrobocia. Są one dobrą podstawą do programowania polityki publicznej, której celem jest ograniczanie społecznych i ekonomicznych skutków trwałego bezrobocia.

Wartością analizy i zrozumienia refleksji społecznej Bourdieu jest obrazowe ukazanie przyczyn i skutków zjawisk, które często uwarunkowane są transpozycjami ogólnospołecznymi i strukturalnymi w różnych kontekstach społecznych (gospodarka, polityka, sztuka, nauka, religia, oświata, bezrobocie itp.). Jest to możliwe poprzez wyodrębnienie pola jako swoistego mikrokosmosu wewnątrz wszechświata społecznego, rządzącego się swoją logiką, mającego względną autonomię, tworzącego właściwy sobie rodzaj praktyk i układów stosunków między uczestnikami (takiego pola, jakie możliwe jest do wyodrębnienia w praktyce). Wówczas to zjawisko bezrobocia nie jest redukowane do problemu indywidualnego osób dotkniętych brakiem 
zatrudnienia, ale przede wszystkim traktowane będzie jako problem zbiorowy (policy problem) (Zybała, 2012: 51). Ważne jest, aby proces demarginalizacji związany był nie tylko z czynnikami subiektywnymi przełamywania bezrobocia, ale przede wszystkim z czynnikami obiektywnymi, zewnętrznymi (zależnymi od roli państwa i polityki publicznej).

\section{Bibliografia}

Bauman, Z. (2004). Życie na przemiał. Kraków: Wydawnictwo Literackie.

Bikont, A. (1988). Tożsamość społeczna - teorie, hipotezy, znaki zapytania, w: Studia nad postrzeganiem relacji Ja - Inni: tożsamość, indywiduacja, przynależność, red. M. Jarymowicz: 432-542. Wrocław: Ossolineum.

Bogle, J.C. (2009). Dość. Prawdziwe miary bogactwa, biznesu i życia. Warszawa: PTE.

Borkowski, T. i Marcinkowski, A. (1999). Socjologia bezrobocia, Katowice: Wydawnictwo Śląskie.

Bourdieu, P. (2006). Przemoc symboliczna, w: Socjologia. Lektury, red. P. Sztompka, M. Kucia: 503-508. Kraków: Znak.

Bourdieu, P. (2006). Struktury, habitus, praktyki, w: Socjologia. Lektury, red. P. Sztompka, M. Kucia: 546-558. Kraków: Znak.

Bourdieu, P. (2013). Pochwała socjologii, Kultura i Społeczeństwo, nr 1: 3-11.

Bourdieu, P. i Wacquant, L.J.D. (2001). Zaproszenie do socjologii refleksyjnej, Warszawa: Oficyna Naukowa.

Business Insider Polska. Totalny rekord. Bez pracy w Polsce pozostaje jedynie 1,1 mln osób.

CBOS (2017). Bezrobotni 2017. http://cbos.pl/SPISKOM.POL/2017/K_051_17. PDF, dostęp 13.03.2018.

Czykwin, E. (2000). Białoruska mniejszość narodowa jako grupa stygmatyzowana, Białystok: Wydawnictwo Trans Humana.

Domański, H. (2009). Społeczeństwa europejskie. Stratyfikacja i systemy wartości, Warszawa: Scholar.

Durkheim, E. (2006). Samobójstwo. Studium z socjologii, Warszawa: Oficyna Naukowa.

Dyczewski, L. (2007). Grupy marginalne, w: Kultura grup mniejszościowych i marginalnych, red. L. Dyczewski: 29-49. Lublin: Wydawnictwo KUL.

Engbersen, G. et al. (1993). Cultures of Unemployment. A Comparative Look at Long-Term Unemployment and Urban Poverty, San Francisco: Westview Press.

GUS (2018). http://stat.gov.pl/obszary-tematyczne/rynek-pracy/bezrobocie-rejestrowane/liczba -bezrobotnych-i-stopa-bezrobocia-rejestrowanego-wyrownane-sezonowo-2011-2018,5,1. html, dostęp 13.03.2018.

https://businessinsider.com.pl/finanse/makroekonomia/stopa-bezrobocia-we-wrzesniu-2017 -dane-mrpips/srl6vyw, dostęp 13.03.2018.

Jarosz, M. i Kozak, M.W. (2015). Eksplozja nierówności?, Warszawa: Oficyna Naukowa. 
Jarymowicz, M. (1988). Studia nad postrzeganiem relacji Ja - Inni: tożsamość, indywiduacja, przynależność. Wrocław: Ossolineum.

Kłoskowska, A. (1993). Kultura masowa. Warszawa: PWN.

Konopka, D. (2009). Kultura bezrobotnych - konieczność czy przypadek?. Białystok: Wydawnictwo WSAP.

Kowalik, T. (2013). Czy i kiedy współpraca socjologów z ekonomistami jest możliwa?, w: O lepszy ład społeczno-ekonomiczny, red. T. Kowalik: 11-13. Warszawa: Polskie Towarzystwo Ekonomiczne i Instytut Nauk Ekonomicznych PAN.

Mączyńska, E. (2009). Słowo wstępne, w: J.C. Bogle, Dość. Prawdziwe miary bogactwa, biznesu i życia. Warszawa: PTE.

Merton, R.K. (1968). The Matthew Effect in Science. Science, 159(3810), January 5: 56-63.

Merton, R.K. (2002). Teoria socjologiczna i struktura społeczna. Warszawa: PWN.

Naylor, J. i Senior, B. (1988). Incompressible Unemployment. Causes, Consequences and Alternatives. Aldershot: Gower Publishing Company Ltd.

Siemaszko, A. (1993). Granice tolerancji. O teoriach zachowań dewiacyjnych. Warszawa: WN PWN.

Szylko-Skoczny, M. (1987). Bezrobocie jako kwestia społeczna. Warszawa: Instytut Pracy i Spraw Socjalnych.

Woś, R. (2017). Żegnaj, NAIRU. Dziennik Gazeta Prawna. 1-3 grudnia 2017, nr 233(4632).

Zybała, A. (2012). Polityki publiczne. Doświadczenia w tworzeniu i wykonywaniu programów publicznych $w$ Polsce i innych krajach. Warszawa: KSAP. 